Article

\title{
Material Flow Cost Accounting as an Approach to Improve Resource Efficiency in Manufacturing Companies
}

\section{Mario Schmidt $^{1, *}$ and Michiyasu Nakajima ${ }^{2}$}

1 Institute for Industrial Ecology INEC, Pforzheim University, Tiefenbronner Str. 65, Pforzheim D-75175, Germany

2 Faculty of Commerce, Kansai University, 3-3-35, Yamate-cho, Suita, Osaka 564-8680, Japan; E-Mail: nakajima@kansai-u.ac.jp

* Author to whom correspondence should be addressed; E-Mail: mario.schmidt@hs-pforzheim.de; Tel.: +49-7231-28-6406; Fax: +49-7231-28-7406.

Received: 28 June 2013; in revised form: 9 August 2013 / Accepted: 15 August 2013 /

Published: 3 September 2013

\begin{abstract}
What potentials do manufacturing companies have for identifying inefficiencies in their use of resources? Assessing the products with regard to their durability, functional usefulness, use of materials, etc. is only one aspect of the exercise. The actual production operations and the search for in-plant inefficiencies represent the other. In Germany, the material flow cost accounting (MFCA) method was developed years ago to tackle this requirement. It evaluates material losses in the company in monetary terms and thus points up the economic benefit of resource efficiency. MFCA first achieved practical relevance and large-scale application in Japan. Now there is even an ISO standard on the method. The article outlines the process and presents typical examples. It explains how a methodological bridge can be built to assess the loss of material in ecological terms too.
\end{abstract}

Keywords: material flow cost accounting (MFCA); ISO 14051; resource efficiency; loss of material; hidden costs; hidden carbon footprint

\section{Introduction}

If we consider the material flows in our society, we see that a substantial share of residual materials is generated in production. Schmidt-Bleek (1994) reckons that the volume of production wastes (without water and air) that then occur dissipatively through product use and product wastes is as much 
as a quarter (Figure 1) [1]. Current figures too reveal considerable quantities. In 2010 production waste of German companies (12.28 million tons) were even higher than the product waste (10.74 million tons) [2]. However, a material loss in the production means a non-productive and huge amount of input in the upstream prechain as shown in Figure 1.

Figure 1. Schmidt-Bleeks' figure of the material flows in Germany. More than half of the masses moved anthropogenically from the deposits do not enter the business cycle. According to [1].

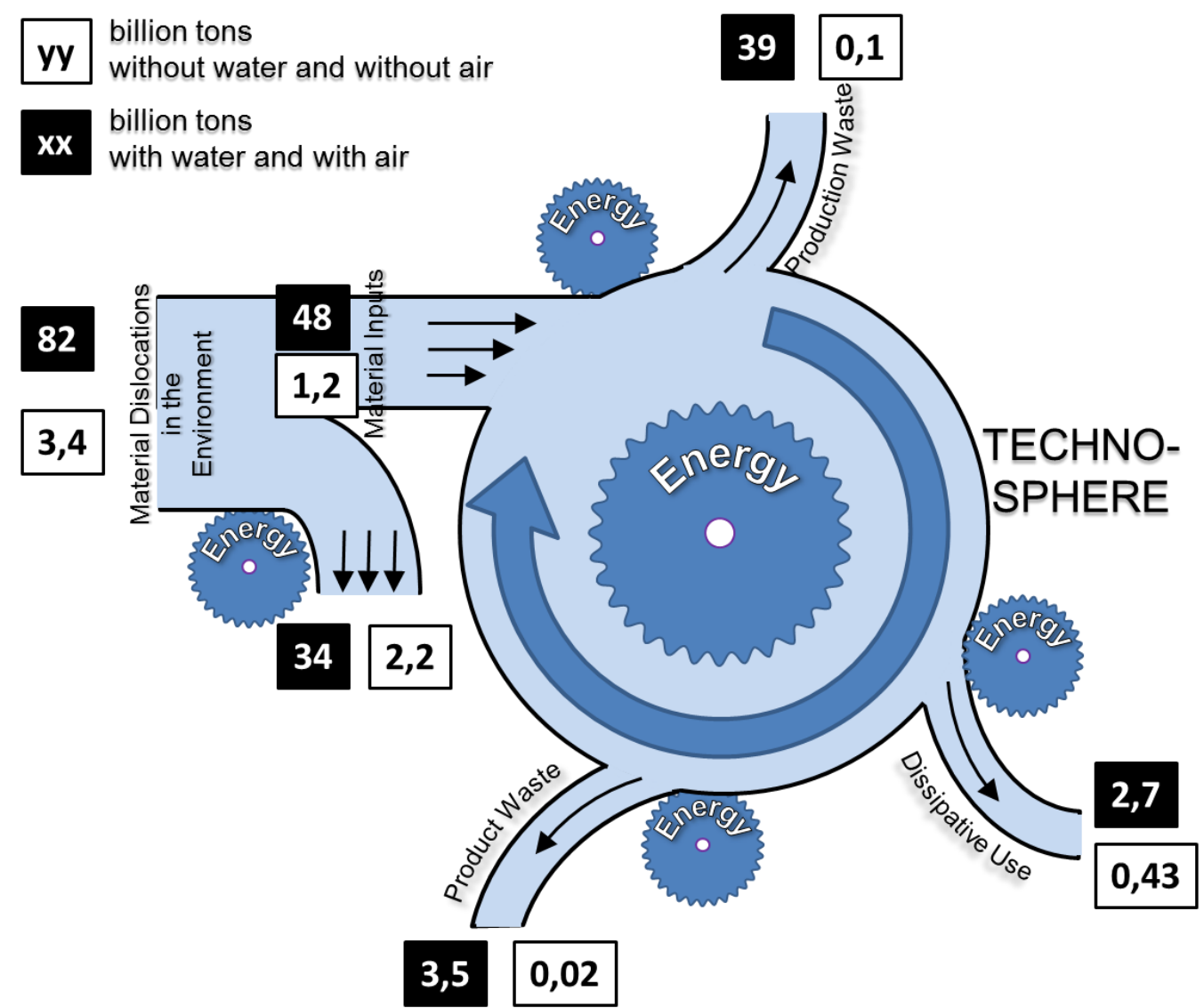

The issue of avoiding residual materials in companies is therefore one of the core motives behind Industrial Ecology or Cleaner Production [3,4]. However, the question arises as to how potentials for savings can be identified. Balancing on a purely volume basis in $\mathrm{kg}$, as has been done in company environmental balances ("gate-to-gate") since the 1990s, is not sufficient for this. It has the disadvantage that the results are neither ecologically nor economically informative. On the one hand the indirectly induced environmental effects outside the company are not taken into account, e.g., the ecological backpack of the materials used in the pre-chain or post-chain. In the context of Life Cycle thinking this is now being taken into consideration more frequently. The ISO 14.040 standard has contributed to this.

On the other hand, there is a lack of monetary value data for the material flows, as their economic relevance still determines what is done with these materials. Is elimination of the residual materials expensive? Can one therefore save costs by reducing the quantities of residual materials? Or are the residual materials worth so much that it is even worth recycling them, such as is the case, e.g., with 
expensive metals? The answers are of significant importance for company management in order to decide whether it is commercially worth taking the necessary measures. Investments are frequently necessary before other or additional technical processes can be implemented. Precise knowledge of the potential for monetary savings is therefore a prerequisite for actually using material-conserving methods.

\section{Historical Development}

With the upcoming environmental management systems of the 1990s, the issue of reducing operational material and energy inputs was considered as a common goal of economic and environmental interests [5]. Initial approaches with flow cost accounting were pursued [6,7]. Flow cost accounting tried to quantify and evaluate all material and energy flows of a defined production system, first in kilograms and then tying them to the existing cost accounting.

In addition, "residual material cost accounting" was developed, which adopted a similar approach and aimed to record the costs accumulated in the residual substances from production. This too worked on the basis of quantities expressed in kilograms. In addition to the actual costs of disposal, the residual substance costs also include the material value resulting from the price of the raw materials purchased, the costs of the value adding component that has accumulated in the materials, costs of storage, handling of the residual materials and environmental protection activities.

By contrast with conventional cost accounting approaches, flow cost accounting and residual material cost accounting are based on the quantity structure (in kilograms) and they expressed their results in costs (in Dollars or Euros). Both approaches also transfer a cost component to the residual materials of a production system and thus identify the residual materials as a further cost unit [5]. This makes it possible to express the potentials for saving in monetary terms.

The methodologies were devised in the 1990s by many pilot projects in Germany, for instance at Ciba Geigy Pharma-Deutschland GmbH, ITT Automotive GmbH or the Merckle-Ratiopharm Group and tested in company practice. The methodology was documented e.g. in several guides [8,9]. Many of the studies can be traced back to the Institut für Management und Umwelt (IMU) Augsburg and its Director Bernd Wagner [10].

After state promotion was phased out, the method was hardly used in Germany any more. However in Japan the method was applied for the first time in 2000 and soon became widespread under the name Material Flow Cost Accounting. The Japanese Ministry of Trade and Industry (METI) in particular funded the first case studies (e.g., at the firm Nitto Denko) and recommended further application of the idea [11]. Since then, further METI-financed projects have been continued in order to develop the method and application context of MFCA further. Today the number of companies in Japan that have gathered experience with MFCA is over 300. Meanwhile, numerous studies on the method and practical experience have been published again, especially in Japan and in Germany [12-15].

In the year 2007, Japan suggested developing a norm on MFCA within the ISO 14000 family. The objective was to set out and standardize the general principles and frameworks for material flow cost accounting in order to support greater dissemination of the method and thus contribute worldwide to more efficient handling of resources in companies. In particular representatives or consultants of small and medium-sized companies were to be familiarized with MFCA through the simplicity of its basic concept and its scalability. However, it was not to be developed to a certifiable process as it generally 
only addresses in-company aspects that are not communicated to the exterior. A number of countries were involved in drawing up the norm at ISO. Alongside Japan and Germany, these included for example Brazil, the United Kingdom, Finland, Malaysia, Mexico and South Africa. This norm was adopted in 2011 and published as ISO 14051.

\section{Methodological Approach}

Figure 2 shows the essential idea behind MFCA. In classic cost accounting all costs would only be allocated to the product as cost unit. In MFCA the material costs are divided between the product and the residual materials, depending on where the materials end up. In addition, system costs that can be generated in companies by storage, processing or transport are added. These are also divided between products and residual materials on the basis of suitable key indicators. This allocation can - but need not — be carried out on the basis of physical quantities.

Figure 2. Distribution of the various costs in the flows to products and residual materials.

According to [16].

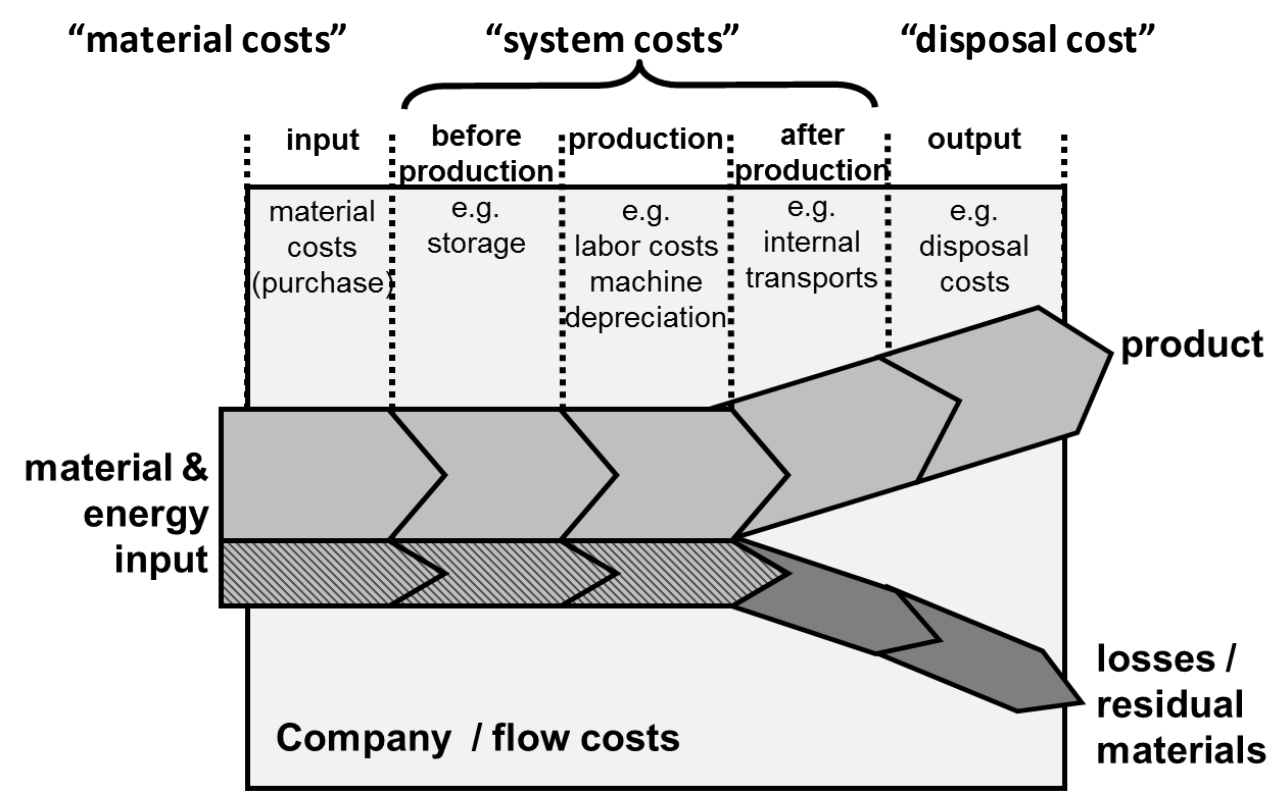

The costs of the material losses can now provide indications for improvement measures. Potentials for reducing costs exist in particular in avoiding material losses. The monetary savings are distinctly higher than if only the direct costs of waste disposal are assessed for the residual materials. This means, for example, that the amortization periods for investment to reduce residual material quantities are shorter and open up greater scope for measures in quality or environmental management.

Figure 3 shows a simple material flow model as is described in ISO 14051. The prices for the materials $\mathrm{X}, \mathrm{Y}$ and $\mathrm{Z}$ are 100,40 and $20 \$ / \mathrm{kg}$ respectively. The material flows are shown by means of Quantity Centres (QC1) with their material inputs and outputs. The distribution of the material costs is based on this. In the flow cost matrix, for example, the material costs of QC1 are stated as $\$ 6200$ $(50 \mathrm{~kg} \times 100 \$ / \mathrm{kg}+30 \mathrm{~kg} \times \$ 40)$. This is distributed between the product and the material loss in accordance with the flow quantities, in other words $\$ 5200$ to the product and $\$ 1000$ to the material 
loss. In a multi-stage production system the costs are then passed on to the next QC. Other costs are handled in the same way. However, the costs of waste disposal are allocated solely to material loss.

Figure 3. Material flow model according to ISO 14051 for a simple (a) two-stage production system; (b) and the associated flow cost matrix [17].

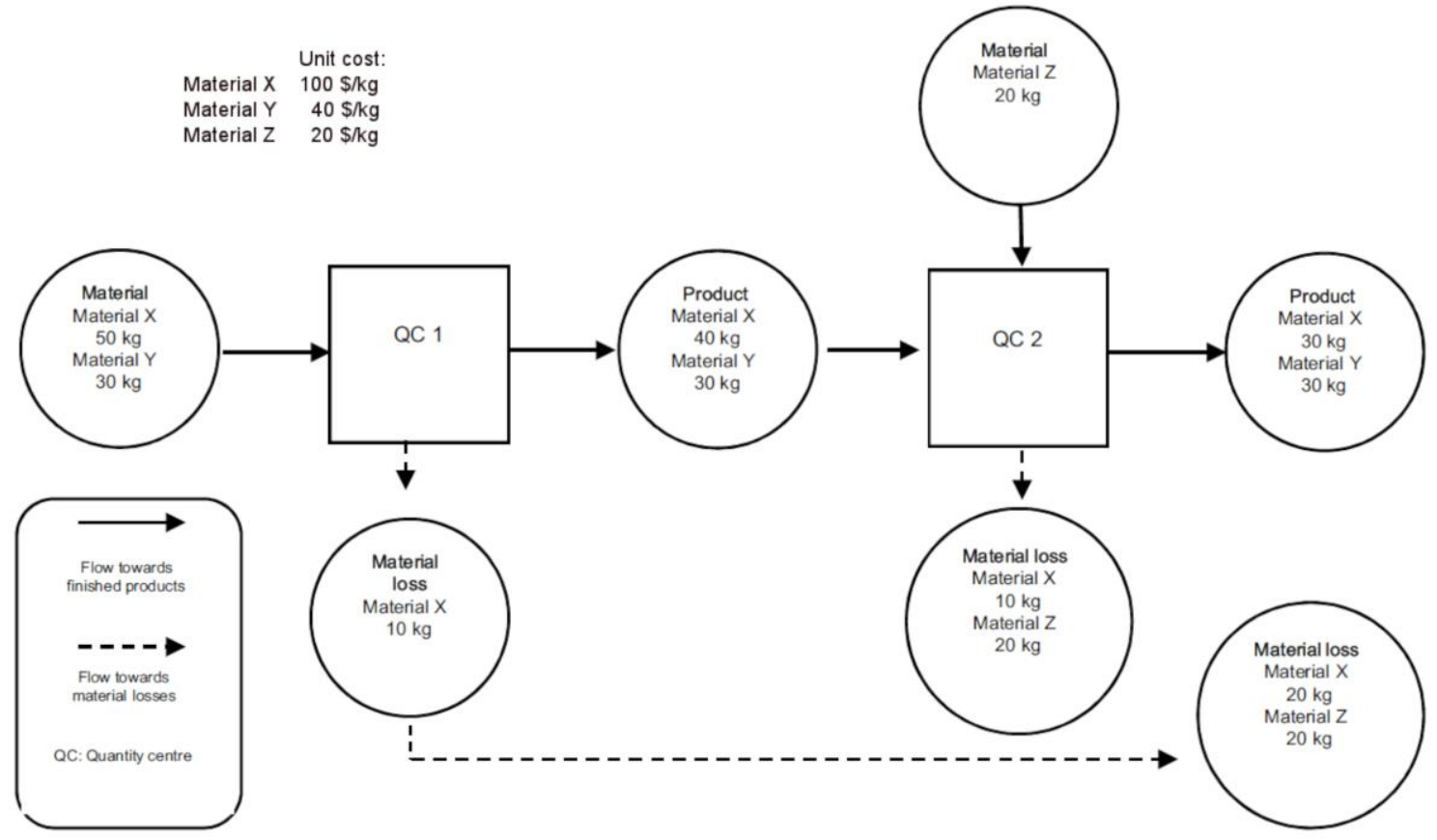

(a)

\begin{tabular}{|c|c|c|c|c|c|c|c|c|c|c|}
\hline & \multicolumn{5}{|c|}{ QC 1} & \multicolumn{5}{|c|}{ QC 2} \\
\hline & $\begin{array}{l}\text { Material } \\
\text { costs }\end{array}$ & $\begin{array}{l}\text { Energy } \\
\text { costs }\end{array}$ & $\begin{array}{l}\text { System } \\
\text { costs }\end{array}$ & $\begin{array}{c}\text { Waste } \\
\text { management } \\
\text { costs }\end{array}$ & Total & $\begin{array}{l}\text { Material } \\
\text { costs }\end{array}$ & $\begin{array}{l}\text { Energy } \\
\text { costs }\end{array}$ & $\begin{array}{l}\text { System } \\
\text { costs }\end{array}$ & $\begin{array}{c}\text { Waste } \\
\text { management } \\
\text { costs }\end{array}$ & Total \\
\hline $\begin{array}{l}\text { Inputs from } \\
\text { previous QC }\end{array}$ & & & & & & $\$ 5200$ & $\$ 350$ & $\$ 700$ & & $\$ 6250$ \\
\hline $\begin{array}{l}\text { New inputs in } \\
\text { QC }\end{array}$ & $\$ 6200$ & $\$ 400$ & $\$ 800$ & $\$ 300$ & $\$ 7700$ & $\$ 400$ & $\$ 300$ & $\$ 1200$ & $\$ 400$ & $\$ 6200$ \\
\hline $\begin{array}{l}\text { Total in each } \\
\text { QC }\end{array}$ & $\$ 6200$ & $\$ 400$ & $\$ 800$ & $\$ 300$ & $\$ 7700$ & $\$ 5600$ & $\$ 650$ & $\$ 1900$ & $\$ 400$ & $\$ 8550$ \\
\hline Products & $\$ 5200$ & $\$ 350$ & $\$ 700$ & & $\$ 6250$ & $\$ 4200$ & $\$ 433$ & $\$ 1267$ & $\$ 400$ & $\$ 5900$ \\
\hline $\begin{array}{l}\text { Material } \\
\text { losses }\end{array}$ & $\$ 1000$ & $\$ 50$ & $\$ 100$ & $\$ 300$ & $\$ 1450$ & $\$ 1400$ & $\$ 217$ & $\$ 633$ & $\$ 400$ & $\$ 2650$ \\
\hline $\begin{array}{l}\text { Total costs of } \\
\text { material } \\
\text { losses in this } \\
\text { process }\end{array}$ & & & & & & $\$ 2400$ & $\$ 267$ & $\$ 733$ & $\$ 700$ & $\$ 4100$ \\
\hline $\begin{array}{l}\text { Total costs in } \\
\text { this process }\end{array}$ & & & & & & $\$ 6600$ & $\$ 700$ & $\$ 2000$ & $\$ 700$ & $\$ 10000$ \\
\hline
\end{tabular}

(b)

As a result of this, the complete costs of the material loss can be stated. In this example they are $\$ 4100$, of which $\$ 1000$ represent pro-rated energy and system costs in the company. These costs could be saved if the material loss were avoided. In practice, however, generally only the $\$ 700$ as waste disposal costs are perceived as material loss costs. At any rate, if one knows the complete costs quite different economic scope opens up for technical measures in order to reduce the material loss. That is the advantage of the MFCA analysis. 
From the point of data availability MFCA looks like conventional cost accounting, but those cannot give all the required data. Conventional cost accounting traces monetary value flows and interprets them as costs of products or of the whole company or subsystems. It focuses on the accuracy of cost figures for each product in each process, and pays attention to the consistency between the sum of product costs and periodical manufacturing costs, based on bookkeeping or accounting standards.

In contrast, MFCA first checks the mass balances in each process. Usually, a company knows what the main input materials of each process are, and how many products are produced from these inputs. However, normally it does not know how much material losses are generated in the specific process. Typically, the figures for waste are only known for the whole company or a larger division. Therefore, it is an important step to identify the real losses of each process. A similar problem occurs concerning the common costs for auxiliary materials and energy. Again, many data are only available for the company overall. At this point, a detailed mass balance of each relevant process provides a good basis for MFCA. The weights of input materials, outputs and materials losses as well as energy consumption are measured, and an extended bill of material is made for each process. This is done step by step for the whole production line of a specific product or production order. The result is a material flow model as shown in Figure 3. However, these flows are eventually valuated in monetary terms (see cost matrix).

Many Japanese companies understand MFCA as a new "Kaizen". Usually, they collect most of the data by measuring the real production situation, and then they visualize the current situation. For that, help is needed from cross functional sections, for example, production section, engineering section, plant management section, cost management section, environmental management section, etc. If data from management information systems are used measurements on the shop floor would not be needed. However, in this case, inconsistency in the data of the management would not be identified and the real material losses could not be calculated. Therefore, the companies should learn the accuracy and relevance of their own data and the importance of data collection and cost evaluation.

\section{The Example of Canon}

The Japanese firm Canon is one of the best known and largest camera producers in the world. At the Utsunomiya Plant (Japan) an MFCA was carried out as an experiment where one of the authors was involved. The subject of the test was lens production for single lens reflex cameras.

In lens production, considerable quantities of waste material resulted from the grinding process. In conventional accounting only the defective products had been recorded, accounting for about $1 \%$. However, application of the MFCA showed that a large part of the costs are connected with the material losses due to defective products, wastes, etc. (Figure 4). Applying MFCA, the costs were now divided between the actual products (the "positive" products) and the wastes. In Japan the term "negative" products was introduced for the latter group in order to make it clear to the workforce in the companies that these material quantities are undesirable.

Figure 5 comprises a flow chart showing how the various costs are distributed along the process chain at Canon. For each machining process, the cost of raw materials, the system costs and the disposal costs are recorded and distributed between the outputs. It turns out that $32 \%$ of the costs can be allocated to the material loss. 
Figure 4. Conventional cost accounting and material flow cost accounting (MFCA) for lens production. [19].

\section{Conventional Production Management}
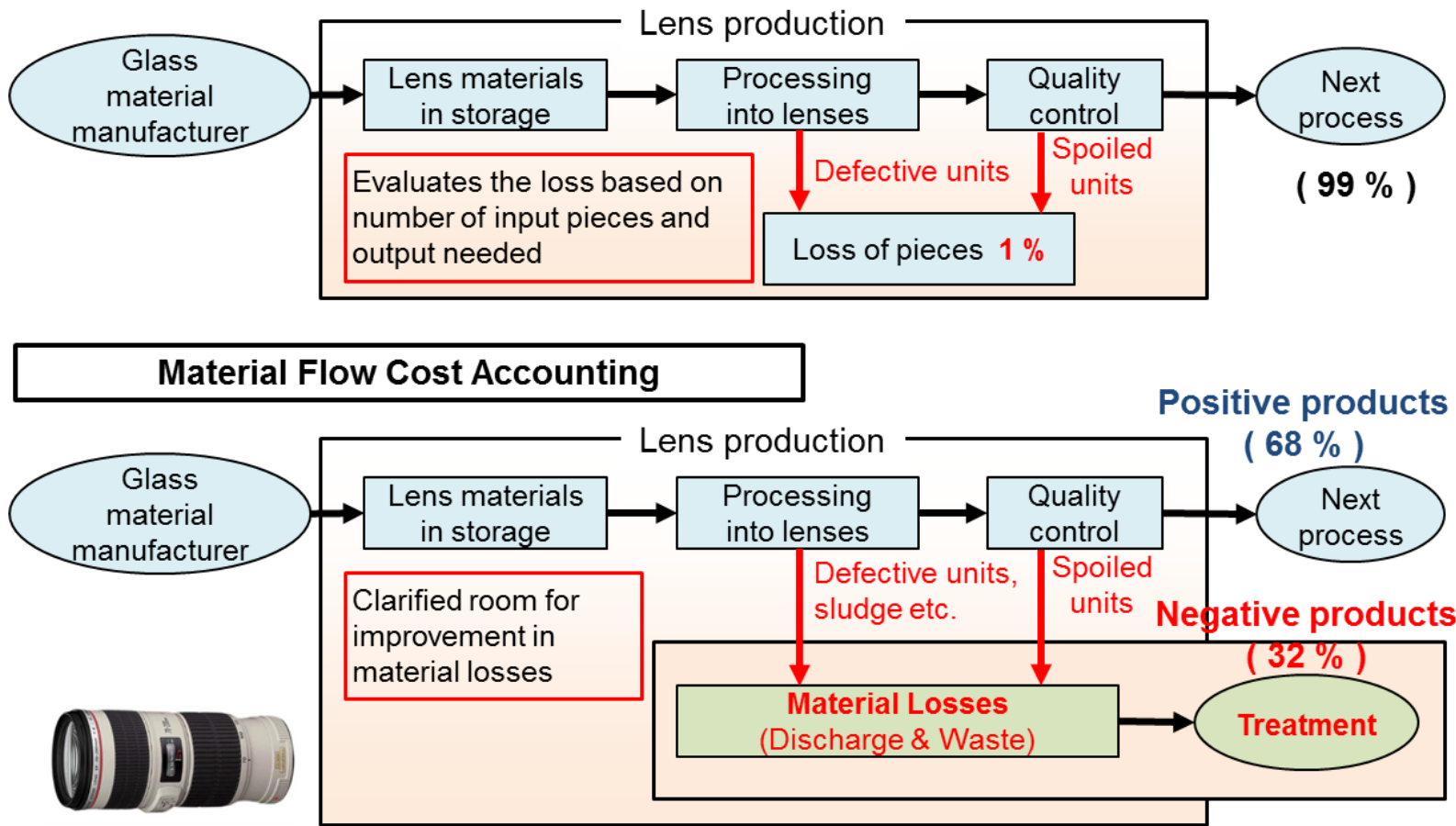

Figure 5. Flow chart representation of the cost distribution between product and material losses in the example of the lens at Canon.

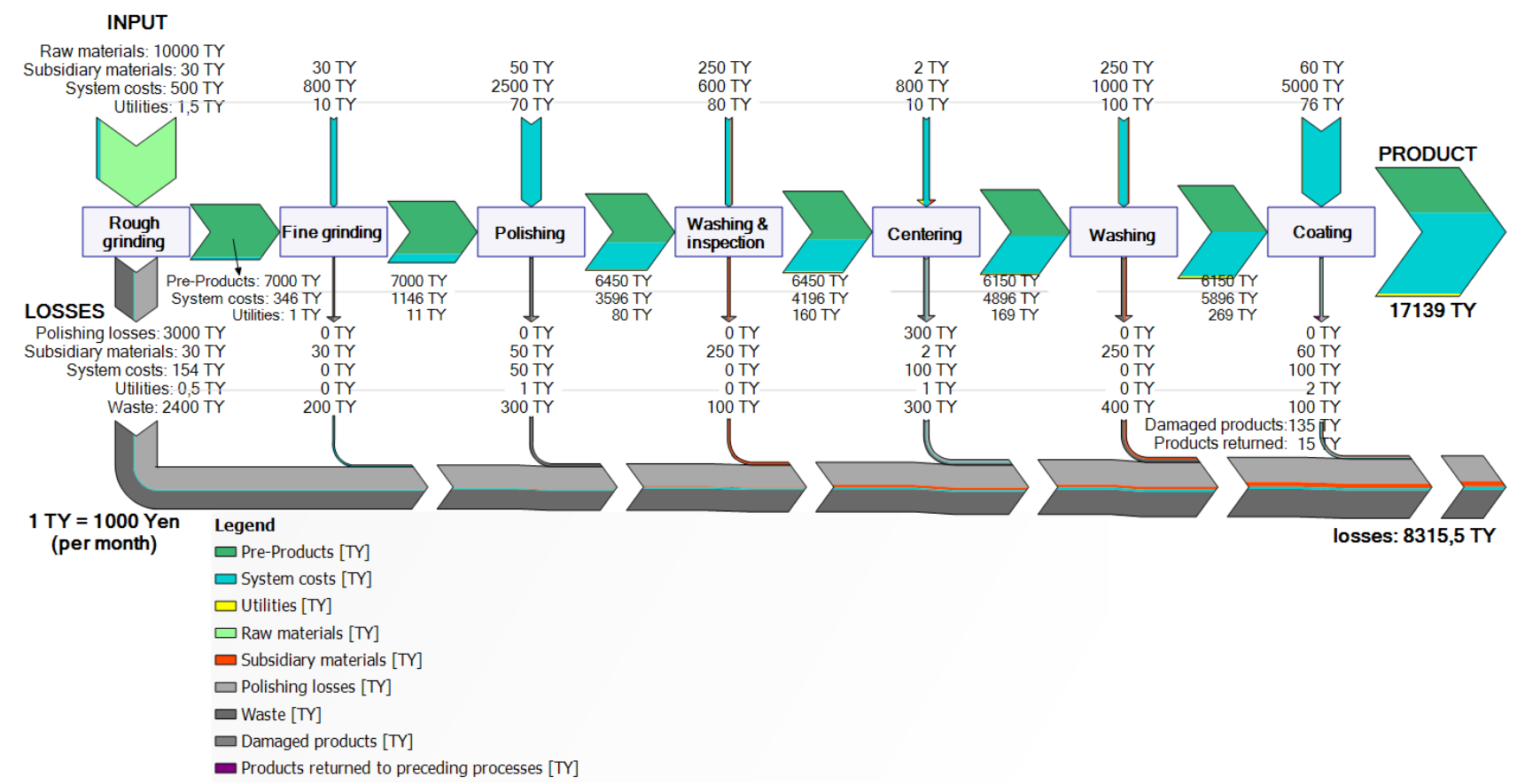

Approximately $2 / 3$ of the material loss cost was generated in grinding processes. The material loss cost is mostly composed of material cost of sludge and treatment cost of waste water. The amount of 
sludge could be reduced drastically by adoption of so called "near-shaping" lenses in cooperation with the suppliers of the lens blanks (Figure 6).

Following this first encouraging application of the method, MFCA was then successfully applied to roller units for toner cartridges too. After this, MFCA was expanded to Canon production sites outside Japan. In 2005 introduction at Canon's suppliers was started. Finally, in 2010, the use of MFCA for technical innovations in the production sector was launched too.

By December 2012 MFCA had been introduced at 17 Canon plant sites at home and abroad. The costs saved between 2004 and 2012 amount to altogether Yen 5.1 billion, equivalent to around US \$51 million. The savings were achieved chiefly through having to purchase less material. With the savings it was also possible to show above all that environmental protection measures not only reduce environmental burdens and lower the consumption of resources, but can also bring economic benefits to companies by reducing their costs.

Figure 6. Material loss in the conventional production method for lenses and the "near-shaping lens" method of Canon [19].

\section{Near-shaping lens}

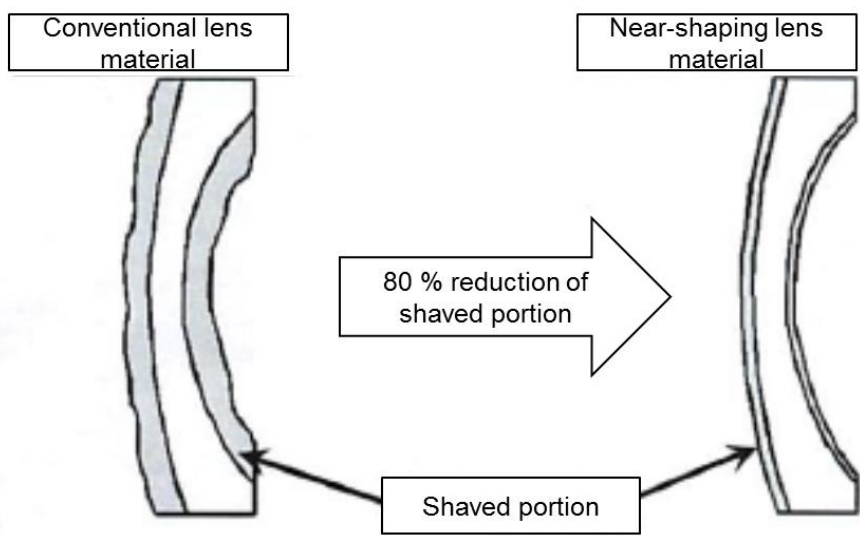

\section{Further Experiences}

The projects in the Japanese firms reveal amazing potentials for savings [18]. A selection of 15 case studies in different companies from different branches of industry showed that on average about $20 \%$ to $30 \%$ of the costs are tied up in the "negative" products (Figure 7). The companies concerned have generally already implemented numerous measures to reduce their material flows. It was therefore all the more surprising that the MFCA method was able to disclose further, previously hidden material losses in their production processes.

A crucial aspect of the MFCA method is the analysis of the value chain across a number of process steps. The advantage lies in the fact that this conveys the information about value losses over various process steps and makes it transparent. There is also a similarity with environmental analysis methods such as the Life Cycle Assessment here, which also contain important information in the process chain of the products and pre-products.

In LCAs the data research is limited to quantity data in $\mathrm{kg}$, in other words only the input quantities of the various raw materials and the output quantities of the emissions and wastes have to be 
determined, etc. However, in MFCAs the cost data are relevant too-the costs of materials and the costs of machining processes, e.g., caused by labor, energy, depreciation, etc. If such surveys are only carried out in a single firm, then surveying these data, including the monetary data, is simply a problem of outlay. The data have to be retrieved from the bookkeeping and correctly allocated to the various work areas of a company.

Figure 7. Distribution of potentials for savings in 15 case studies from Japanese industry.

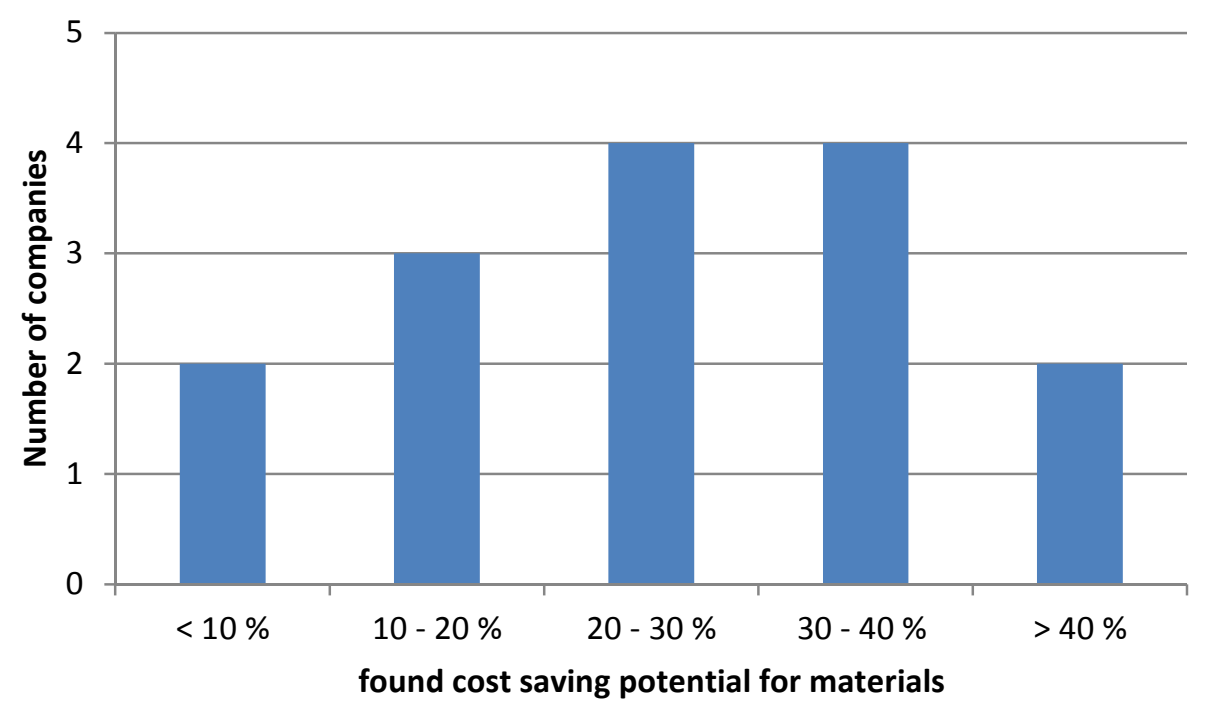

However, as a result of the low vertical depth of manufacture in factories, many production chains are distributed among various companies. This means that intermediate products are passed on B2B from supplier to customer. Although the customer knows the value of the product (naturally calculated according to conventional cost accounting), he has no information about the material loss (in $\mathrm{kg}$ ) and the value of the material loss (in \$). For this he would have to be able to look into the internal cost structure of his supplier. Experience shows that the material loss is spread over the entire chain and that many measures have to be applied at the beginning of the chain. For example, the solution for the lenses at Canon was also found in cooperation with the lens supplier. However, this presupposes that companies cooperate with their suppliers and exchange data. This in turn requires a high measure of trust between the companies.

In Japan such cross-company projects are now being carried out. Figure 8 shows a process chain in which three suppliers (press work, heat treatment, plating work) appear in the chain before the OEM then manufactures the end product. The large mass flows occur at the suppliers. In some cases these might consist of large quantities of water that perhaps do not always play a crucial economic role. However, in countries with water shortages, the use of water can be of major environmental significance.

The challenge of cross-company projects is the common aversion to change detailed cost information between supplier and customer. In some cases (e.g., in the automotive sector) the market power of a company could help. However, in many Japanese projects the exchange of information was limited to physical flows and technical issues and the handoff of cost information was avoided. The aim was that both the supplier and the own company should achieve savings and should profit from it. 
Figure 8. MFCA in a value chain with several processes and companies.

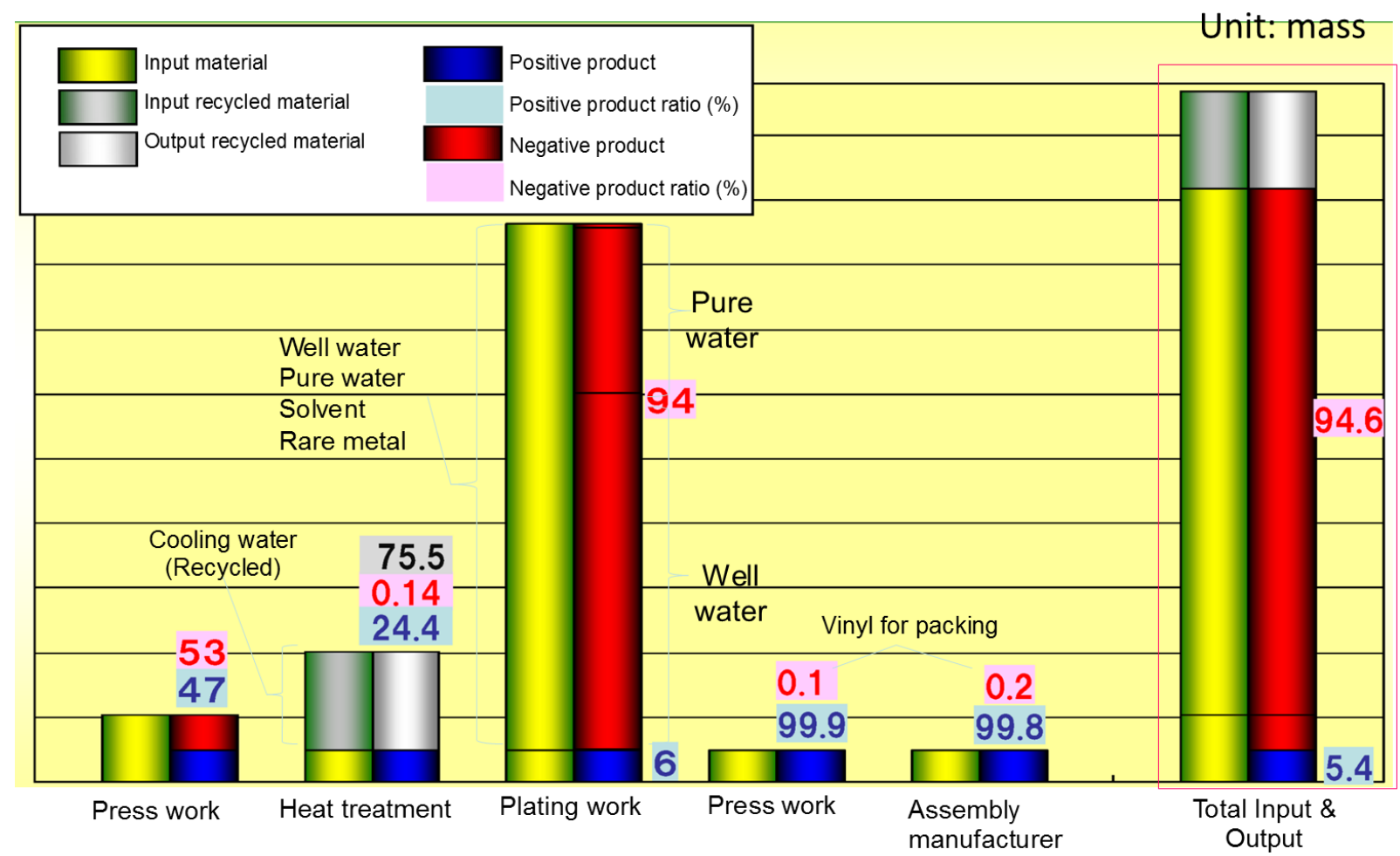

\section{Prospects}

With the cross-company approach it also becomes possible to undertake not only economic assessments, but also environmental assessments of the material loss. From the company's point of view the most relevant question chiefly concerns what costs can be saved in the overall system by avoiding inefficiencies and material loss. The "positive" products can become cheaper as a result; the material input would then drop automatically.

However it is also possible to ask how much environmental burden can be saved if these inefficiencies in production are avoided. For example, it would be possible to calculate how much unnecessary $\mathrm{CO}_{2}$ emission is connected with the material loss. If it were possible to avoid this material loss, in addition to saving costs and input resources it would also be possible to reduce the $\mathrm{CO}_{2}$ emissions or the water consumption across the overall production chain.

An expanded MFCA that also takes such environmental factors into account is currently being developed both in Japan and in Germany. For this the MFCA data are being supplemented with data from the LCA sector. Concrete results, both for the expanded methods and for the first case studies, are expected in the year 2014 .

\section{Acknowledgements}

This research was partially supported by "the Environmental Research and Technology Development Fund (E-1106) of the Ministry of the Environment, Japan" and "KAKENHI (22530503), Grant-in-Aid for Scientific Research (C), Japan" and by the Ministry of Environment of the State of Baden-Wuerttemberg in Germany (Project MEKKA). 


\section{References}

1. Schmidt-Bleek, F. Wie Erreichen Wir Eine Zukunftsfähige Wirtschaft; Wuppertal Institut für Klima, Umwelt, Energie GmbH: Wuppertal, Germany, 1994.

2. Statistisches Bundesamt. Umweltnutzung und Wirtschaft: Tabellen zu den Umweltökonomischen Gesamtrechnungen, Teil 1; Statistisches Bundesamt: Wiesbaden, Germany, 2012.

3. Frosch, R.A.; Gallopoulos, N.E. Strategies for manufacturing. Sci. Am. 1989, 94-102.

4. Fresner, J. Cleaner production as a means for effective environmental management. J. Clean. Prod. 1998, 6, 171-179.

5. Loew, T.; Fichter, K.; Müller, U. Ansätze der Umweltkostenrechnung im Vergleich; Umwelt-bundesamt: Berlin, Germany, 2003.

6. Wagner, B.; Rauberger, R. Ecobalance Analysis as a Managerial Tool at Kunert AG. In Sustainable Measures; Bennett, M., James, P., Eds.; Greenleaf: Sheffield, UK, 1999; pp. 170-184.

7. Wagner, B.; Strobel, M. Kostenmanagement mit der Flusskostenrechnung. In Werkzeuge erfolgreichen Umweltmanagements; Freimann, J., Ed.; Gabler: Wiesbaden, Germany, 1999; pp. 49-70.

8. Landesanstalt für Umwelt Baden-Württemberg (LfU). Leitfaden Betriebliches Material und Energieflussmanagement-Öko-Effizienz durch nachhaltige Reorganisation; LfU: Karlsruhe, Germany, 1999; p. 35.

9. Hessisches Ministerium für Wirtschaft; Verkehr und Landesentwicklung. Leitfaden Flusskostenmanagement - Kostensenkung und Öko-Effizienz durch eine Materialfluss-Orientierung in der Kostenrechnung; Hessisches Ministerium für Wirtschaft, Verkehr und Landesentwicklung: Wiesbaden, Germany, 1999; p. 72

10. Berger, M.; Enzler, S.; Kammerer-Kirch, E.; Luger, M.; Müller, U.; Redmann, C.; Strauß, T.; Strobel, M.; Wagner, B. Flow Management for Manufacturing Companies Sustainable Re-Organisation of Material and Information Flows; Imu Augsburg GmbH \& Co. KG und Zentrum für Weiterbildung und Wissenstransfer: Augsburg, Germany, 2003.

11. Ministry of Economy, Trade and Industry of Japan (METI). Guide for Material Flow Cost-Accounting (Ver.1); METI: Tokyo, Japan, 2007.

12. Nakajima, M. The Chapter 2: Environmental Management Accounting to Support Cleaner Production, Management Systematization of Material Flow Cost Accounting. In Environmental Management Innovation 5: Accounting System to support Environmental Management Decision-making (in Japanese); Ueda, K., Kokubu, K., Eds.; Chuokeizai-sha: Tokyo, Japan, 2011; pp. 27-50.

13. Nakajima, M.; Kimura, A. Promotion of innovative improvement integrated MFCA with budgeting (in Japanese). J. Cost Account. Res. 2012, 36, 15-24.

14. Viere, T.; Möller, A.; Schmidt, M. Methodische behandlung interner materialkreisläufe in der materialflusskostenrechnung. Umweltwirtschaftsforum 2010, 18, 203-208.

15. Wagner, B.; Nakajima, M.; Prox, M. Materialflusskostenrechnung-Die internationale karriere einer methode zur identifizierung von ineffizienzen in produktionssystemen. Umweltwirtschaftsforum 2010, 18, 197-202. 
16. Strobel, M.; Redmann, C. Flusskostenrechnung, Systematische Kostensenkung und Umweltentlastung durch eine Flussorientierung in der Kostenrechnung. In Proceedings of Umweltkostenrechnung für Betriebe-Zwischen Anspruch und Praxis, Workshop of "AK Ökologische Unternehmensführung FH Pforzheim”, Pforzheim, Germany, 16 June 2000.

17. Schmidt, M. Material Flow Cost Accounting in der produzierenden Industrie. In Industrial Ecology Management; Von Hauff, M., Isenmann, R., Müller-Christ, G., Eds.; Springer Gabler: Wiesbaden, Germany, 2012; pp. 241-255.

18. Ministry of Economy, Trade and Industry of Japan (METI). Environmental Management Accounting: MFCA Case Examples; METI: Tokyo, Japan, 2010.

19. Furuta, K. Canon's Environmental Activities \& Utilization of MFCA. Canon Headquarter: Tokyo, Japan, 21 May2013.

(C) 2013 by the authors; licensee MDPI, Basel, Switzerland. This article is an open access article distributed under the terms and conditions of the Creative Commons Attribution license (http://creativecommons.org/licenses/by/3.0/). 